\title{
Flood Management Current State, Challenges and Prospects in Pakistan: A Review
}

\author{
MUHAMMAD ASLAM*† \\ RECEIVED ON 19.12.2016 ACCEPTED ON 29.05.2017
}

ABSTRACT

Flooding is globally a major natural hazard. Floods result in property and life loss and poor economic development. Though it is not possible to prevent the occurrence of floods, but their negative impacts could be minimized considerably through proper planning and effective preparation. The vulnerability to floods could be reduced by accurate and timely prediction (Forecasting and Warning) and by impactreducing measures. Pakistan faces flooding problem almost every year in the recent past. For the period 1947-2015, a financial loss of US $\$ 38.165$ billion has been estimated as a result of 23 major flood events in Pakistan. Approximately, more than 12,000 human beings were dead and $616,598 \mathrm{~km}^{2}$ land area was affected due to these floods. Climate change has been projected to lead to an increase in the frequency and magnitude of floods in future in Pakistan due to high glacial melting and deicing of mountain caps and high monsoon rainfall. The situation demands for effective and sustainable flood management to reduce flood damages. This paper reviews flood management current state, highlights challenges of flood management and identifies prospects for effective and sustainable flood management in Pakistan. The paper also seeks to make certain recommendations toward effective and sustainable flood management in Pakistan.

Key Words: Flood Management, Current State, Challenges, Prospects, Pakistan.

\section{INTRODUCTION}

$\mathrm{F}$ looding is globally a major natural hazard. Floods result in property and life loss and poor economic development. Though it is not possible to prevent the occurrence of floods, but their negative impacts could be minimized considerably through proper planning and effective preparation. The vulnerability to floods could be reduced by accurate and timely prediction (Forecasting and Warning) and by impact-reducing measures. Pakistan is also adversely affected by floods. Pakistan faces flooding problem almost every year in the recent past. Floods cause huge loss of infrastructure, life and land. In Pakistan, poor management of water resources and lack of effective water policy have led to flooding problem [1]. It has been reported that among South Asian countries affected by flooding, Pakistan is in fifth place [2]. The historical perspective of floods and the nature and causes of floods in Pakistan are portrayed below. 


\subsection{Historical Perspective of Floods}

Pakistan has a long history of floods. During 1947-2015 period, Pakistan has experienced 23 highest flood events [3]. During this period, floods of different magnitudes damaged large tracts of lands in Gilgit-Baltistan, FATA (Federally Administered Tribal Areas), AJK (Azad Jammu and Kashmir), KPK (Khyber Pakhtunkhwa), Punjab, Sindh and Balochistan. The 2010 super floods in Pakistan was one of the largest river flood in recent history $[4,5]$.

For the period 1947-2015, a financial loss of US\$ 38.165 billion has been reported as a result of 23 major flood events in Pakistan. Approximately, more than 12,000 human beings were dead and 616,598 $\mathrm{km}^{2}$ land area was affected due to these floods as shown in Table 1. On an average, every year floods affect approximately 0.715 population of Pakistan and by 2030 about 2.7 million people in Pakistan may be affected by floods [6-8].

\section{$1.2 \quad$ Types of Floods}

Riverine floods, flash floods, glacial lake outburst floods, coastal floods and the urban floods take place in Pakistan. Main characteristics of these floods are depicted below.

\subsubsection{Riverine Floods}

Riverine floods generally take place as a result of intense monsoon (summer) rainfall in the catchments [9]. In the history of Pakistan, the 2010 super flood was the most devastating riverine flood [10] which caused huge life and financial loss [11]. Agriculture sector (crops, livestock and fisheries) suffered the highest damage caused by 2010 super flood. It was estimated at US\$5045 million as revealed in Table 2 [12]. The 2013 and 2014 riverine floods also caused huge life and property loss.

TABLE 1. HISTORICAL FLOODS AND DAMAGES DISTRIBUTION

\begin{tabular}{|c|c|c|c|c|c|}
\hline No. & Year & $\begin{array}{l}\text { Financial Loss } \\
\text { (US\$ Million) }\end{array}$ & $\begin{array}{c}\text { Human Deaths } \\
\text { (Number) }\end{array}$ & $\begin{array}{c}\text { Damaged Villages } \\
\text { (Number) }\end{array}$ & $\begin{array}{c}\text { Inundated Area } \\
\left(\mathrm{km}^{2}\right)\end{array}$ \\
\hline 1. & 1950 & 488 & 2190 & 10000 & 17920 \\
\hline 2. & 1955 & 378 & 679 & 6945 & 20480 \\
\hline 3. & 1956 & 318 & 160 & 11609 & 74406 \\
\hline 4. & 1957 & 302 & 83 & 4498 & 16003 \\
\hline 5. & 1959 & 234 & 88 & 3902 & 10424 \\
\hline 6. & 1973 & 5134 & 474 & 9719 & 41472 \\
\hline 7. & 1975 & 685 & 126 & 8628 & 34931 \\
\hline 8. & 1976 & 3485 & 425 & 18390 & 81920 \\
\hline 9. & 1977 & 338 & 848 & 2185 & 4657 \\
\hline 10. & 1978 & 2227 & 393 & 9199 & 30597 \\
\hline 11. & 1981 & 299 & 82 & 2071 & 4191 \\
\hline 12. & 1983 & 135 & 39 & 643 & 1882 \\
\hline 13. & 1984 & 75 & 42 & 251 & 1093 \\
\hline 14. & 1988 & 858 & 508 & 100 & 6144 \\
\hline 15. & 1992 & 3010 & 1008 & 13208 & 38758 \\
\hline 16. & 1994 & 843 & 431 & 1622 & 5568 \\
\hline 17. & 1995 & 376 & 591 & 6852 & 16686 \\
\hline 18. & 2010 & 10000 & 1985 & 17553 & 160000 \\
\hline 19. & 2011 & 3730 & 516 & 38700 & 27581 \\
\hline 20. & 2012 & 2640 & 571 & 14159 & 4746 \\
\hline 21. & 2013 & 2000 & 333 & 8297 & 4483 \\
\hline 22. & 2014 & 440 & 367 & 4065 & 9779 \\
\hline 23. & 2015 & 170 & 238 & 4634 & 2877 \\
\hline & Total: & 38165 & 12177 & 197230 & 616598 \\
\hline
\end{tabular}




\subsubsection{Flash Floods}

The flash floods of huge magnitude and short duration take place in natural streams due to heavy monsoon rainfall (torrential rain) in hilly and semi-hilly areas [13-15]. Flash floods are difficult to predict and also have the short warning lead times. In Pakistan, flash floods occur along the mountainous regions adjoining the Indus River Basin, Kashmir, Gilgit-Baltistan, KPK, Balochistan and South Punjab. The flash flood of 2011 caused a human life loss of more than 500 lives. The 2011 floods had severely impacted the agriculture sector, with damages to crops, livestock and fisheries. The total estimated loss was US\$ 1840.31 million. Sindh suffered most with $94 \%$ and Balochistan with $6 \%$ of total agriculture sector damage as depicted in Table 3 [16].

The flash flood of 2012 also caused about 571 human deaths [17]. Crop loss caused by 2012 flash flood was estimated as PKR 33.6 billion [18]. The NDMA (National Disaster Management Authority) reported that 2014 flash floods caused death of more than 200 people and affected over 460,000 people across AJK, Gilgit Baltistan and Punjab [19]. The 2016 flash flood also caused a

TABLE 2. AGRICULTURE SECTOR LOSS DUE TO 2010 FLOOD IN PAKISTAN

\begin{tabular}{|c|c|}
\hline Province/Location & Loss (USD Million) \\
\hline AJK & 24 \\
\hline Balochistan & 427 \\
\hline FATA & 36 \\
\hline Gilgit Baltistan & 22 \\
\hline KPK & 396 \\
\hline Punjab & 1838 \\
\hline Sindh & 2302 \\
\hline Total: & 5045 \\
\hline
\end{tabular}

TABLE 3. AGRICULTURE SECTOR LOSS DUE TO 2011 FLOOD IN PAKISTAN

\begin{tabular}{|c|c|}
\hline Province & Loss (USD million) \\
\hline Balochistan & 103.77 \\
\hline Sindh & 1736.54 \\
\hline Total: & 1840.31 \\
\hline
\end{tabular}

tremendous life and property loss in Chitral of the KPK province [20]. The PDMA (Provincial Disasters Management Authority) in KPK has recently reported that 2016 torrential rains and flash floods during March to July period have killed 261 people in KPK (Chitral, Mardan, Kohat, Manshera and Malakand). Over 200 have been injured and 1,101 houses completely destroyed or washed away, with thousands more partially damaged [21].

\subsubsection{Glacial Lake Outburst Floods}

GLOF (Glacial Lake Outburst Floods) take place as a result of collapse of the glacial lakes [22]. Such floods pose an increasing threat to mountainous regions in northern Pakistan. Three people were killed and over 300,000 people stranded in Chitral, KPK, due to a Glacial Lake Outburst Flood in July 2015.

"The glaciers of the HKH (Himalayan Karakorum Hindu Kush) region in Pakistan are retreating due to global warming. As a result of glaciers retreat, glacial lakes develop behind glacial deposits rupture and release huge volume of water within few hours causing devastating flooding called as GLOF. GLOF causes severe socioeconomic damages in the HKH region of Pakistan. The ICIMOD (International Centre for Integrated Mountain Development) has identified and mapped 5218 glaciers having 2,420 lakes in Pakistan. About 52 lakes have a potential GLOF threat with occurrence frequency of once every 3-10 years. In HKH region, about 35 GLOFs have been reported during the past 200 years. In Pakistan, recently, frequency of bursts floods has increased to 1-2 per year" [23].

\subsubsection{Coastal Floods}

Coastal flooding in coastal areas takes place due to cyclones generated by the storm surges induced by wind in the Arabian Sea. In Pakistan, coastal floods occur due to cyclones in the coastal regions of Balochistan and Sindh during the months of May, June, September and 
October. Pakistan faced 14 cyclones during the 1971-2001 period. In 2007, two consecutive cyclones, namely; Gonu and Yemyin caused coastal floods in Gawadar of Balochistan resulting in huge damages [24].

\subsubsection{Urban Floods}

Flooding in the main cities and the towns takes place due to cloud burst, heavy monsoon rains or cyclones. In Pakistan, vulnerability of urban flooding has also increased. In recent years, Karachi, Lahore and Rawalpindi in Punjab, Karachi and Hyderabad in Sindh and Peshawar in KPK have faced severe flooding problem.

\section{MATERIALS AND METHOD}

The present review study was conducted on flood management in Pakistan. This study mainly focused on riverine and flash flooding. The present study intended to review current state of flood management, highlight flood challenges and identify prospects for effective and sustainable flood management in Pakistan.

The research community in Pakistan has done lot of work to study various aspects of flood management in Pakistan. This has created a good wealth of knowledge on flood management. In the present study, various research and technical reports and papers related to flood management studies and published by different academic, research and consulting institutions were collected and comprehensively reviewed to derive and synthesize key findings on flood management in Pakistan. Key conclusions and recommendations were also derived from the review.

\section{RESULTS AND DISCUSSION}

\subsection{Flood Management Current State}

Pakistan's current flood management system consists of flood policy and strategy, flood laws, flood institutions, flood planning and flood management measures. These elements of flood management system are described below.

\subsection{Flood Policy and Strategy}

The development and implementation of flood policy by government reflects a serious commitment of government towards effective and sustainable flood management. In Pakistan, flood management policy has been recognized in the draft national water policy which has not been approved and implemented yet. The main elements of flood policy include "development of new water storages, improvement of operational rules for reservoirs, improved watershed management, promotion of flood retardation structures, improved maintenance of existing flood infrastructure, improved flood forecasting and warning system, enforcement of laws for flood plains protection and flood zoning” [25].

In Pakistan, the current flood management strategy consists of three elements, namely; (i) flood planning, (ii) flood preparedness, and (iii) flood fighting and post-flood operations [26]. The flood strategy is implemented through deployment of structural and non-structural measures.

\subsection{Flood Laws}

Currently, Pakistan lacks in robust flood management laws [27]. However, existing water laws deal with some of the flood-related legal issues. A River Act vetted by the Law Ministry has been drafted to stop encroachment in floodplains.

\subsection{Flood Institutions}

In Pakistan, flood institutions can be grouped into two categories, namely; (i) flood risk managing institutions which implement structural and non-structural interventions and (ii) flood crisis managing institutions which perform rescue, relief, and rehabilitation tasks [28]. A brief overview of these institutions is depicted below. 


\subsection{Flood Risk Managing Institutions}

Pakistan Commission for Indus Waters: Being a national institute interacts with India regarding the flooding which takes place in the trans-boundary streams.

\section{WADPDA(Water and Power Development Authority):}

Being a national organization performs planning, development and operation of infrastructure to control flooding. "It also collects hydro-meteorological data including river and rainfall from telemetric system installed in the upper catchments of Indus and Jhelum rivers catchments and inflow and outflow data from the Mangla, Tarbela and Chashma reservoirs”.

FFC (Federal Flood Commission): Being a national organization develops and directs implementation of national flood protection plans and supervises flood forecasting and warning activities.

PMD (Pakistan Meteorological Department): Being a national organization performs the tasks of forecasting rainfall and flood and delivering flood warnings.

PIDs (Provincial Irrigation Departments): PIDs are responsible for rivers and riverine surveys, construction, operation, maintenance and management of barrages and flood control infrastructure and implementation of flood management/fighting measures.

\subsection{Flood Crisis Managing Institutions}

Emergency Relief Cell, Cabinet Division/Federal Relief

Commission coordinates relief operations at national level.
NDMA being a national organization supervises and directs rescue and relief activities at country level.

PDMAs carry out flood preparedness task, rescue and relief plans. They coordinate with other provincial departments for these activities.

Provincial Relief Commissions being provincial organizations perform relief activities after floods.

District Administrations being district organizations conduct relief and rescue tasks after floods.

Pakistan Army provides help to other institutions for flood fighting, rescue and relief activities.

\subsection{Flood Planning}

Since 1978, FFC has developed and implemented three 10-year NFPPs (National Flood Protection Plans) as revealed in Table 4. Provincial Irrigation Departments and federal organizations have implemented these plans. The projects implemented under NFPPs mainly included the construction of embankments and spurs, improvement and upgradation of flood forecasting and warning systems and feasibility studies for barrages. The three NFPPs implemented 5240 flood protection schemes at the cost of PKR 25.45 billion as shown in Table 4. During 2008-2009 to 2014-2015 period, 170 flood protection schemes were completed at the cost of PKR 3.9 billion. This way, during 1978-2015 period, 5410 flood protection schemes were implemented at the cost of PKR 29.35 billion.

TABLE 4. AN OVERVIEW OF NATIONAL FLOOD PROTECTION PLANS (NFPP)

\begin{tabular}{|c|c|c|}
\hline Plan & Action & Total Cost (PKR Billion) \\
\hline NFPP-I (1978-1988) & 311 flood-protection schemes completed & 1.73 \\
\hline NFPP-II (1988-1998) & 4444 flood-protection schemes completed & 14.92 \\
\hline NFPP-III (1998-2008) & 485 flood-protection schemes completed & 8.80 \\
\hline Total & 5240 protection schemes completed & 25.45 \\
\hline
\end{tabular}


The fourth 10-year national flood protection plan, NFPPIV (2016-2026) is under approval process. The plan will be implemented during coming ten years subject to its timely approval and provision of financial resources by the GoP (Government of Pakistan). In the meantime, urgently need flood works are being carried out through provincial annual development program and GoP funded flood program. This plan focuses on forestation, restoring of wetlands, floodplains mapping and land use planning in addition to other structural and nonstructural measures. For the first time, this plan focuses on integrated flood management approach and soft measures like restoring forests, wetlands, floodplains mapping and land use planning.

\subsection{Flood Management Measures}

\subsubsection{Structural Measures}

Flood Protection Embankments and Spurs: In Pakistan, the major flood-protection infrastructure comprises 6,807 $\mathrm{km}$ of flood protection embankments and 1,410 spurs. Provincial Irrigation Departments maintain this flood infrastructure.

Water Storage Reservoirs: Reservoirs moderate floods by storing flood water [29]. In Pakistan, Tarbela, Chashma and Mangla reservoirs are used to regulate flood flows during flooding. Flood moderation by reservoirs is not the first priority because the prime function of these reservoirs is to provide water for irrigation and produce electricity. Consequently, their full potential for flood management is not exploited.

\subsubsection{Non-Structural Measures}

Flood Forecasting and Early Warning System: An efficient and effective flood forecasting and early warnings is vital for effective flood management. The flood forecasting and early warning system needs to be expanded and modernized continuously [29]. PMD performs the task of flood forecasting and delivering flood warnings. FFC is implementing different projects to improve and upgrade the flood forecasting and early warning system thereby to make it more efficient and reliable.

Flood Preparedness: Every year before the commencement of monsoon, federal and provincial flood institutions perform a flood preparedness planning. Flood preparedness includes appraisal of the reservoirs, barrages, and levees conditions and decision-making regarding the measures for flood management well in advance.

Flood Fighting and After Flood Activities: During flood, required measures are taken to regulate the flow at grave sites along the rivers. Provincial irrigation departments, WAPDA and Army play a vital role in flood fighting by regulating flood infrastructure. Rescue and relief tasks are planned and performed at district level.

\subsection{Flood Management Challenges}

\subsubsection{Lack of Comprehensive Flood Policy}

Currently, Pakistan does not have approved national water and flood policy [30,31]. Pakistan's draft flood policy seems to consist of a plan rather than a policy. Also, Pakistan's current draft flood policy does not consider the glacial lake outburst floods. Pakistan lacks policy, strategy, and plan specifically dealing with flash floods. Mostly existing policy relates to riverine floods and flash floods are dealt with using the same policy and strategy as riverine floods [32]. The NDRP (National Disaster Risk Reduction Policy) developed in 2013 is also reactive not proactive in addressing disasters. It mainly focuses on response and rescue [33]. Currently, implementation of NDRP does not contribute towards expected reduction in flood damages [34]. 


\subsubsection{Lack of Comprehensive Flood Laws}

The vigorous flood laws are vital for effective flood maangement. Currently, Pakistan does not have comprehensive flood management laws. In Pakistan, already existing water laws developed for specific purposes do not have comprehensive provisions to deal with flood problems. Weak flood legislation and governance have created several challenges at the operational level. Lack of floodplain regulations is also confronting effective flood control in Pakistan.

\subsubsection{Institutional Issues}

In Pakistan, flood institutions lack in capacity to deal with floods effectively [35-38]. Flood institutions also lack in effective coordination. The NDMA and FFC are lagging behind from its stated objectives and responsibilities due to inadequate expertise and technical knowledge required for effective flood management. The NDMA is not playing its role to regulate, coordinate, train the staff and employ latest technologies to develop an effective disaster management system. In the provincial irrigation departments, majority of the irrigation engineers do not have enough capacity to deal with floods effectively. Pakistan Meteorological Department is lacking in modern technology to forecast the flash flooding.

\subsubsection{Planning Issues}

Due to poor support from research Pakistan lacks in formulating effective flood management strategies. Basin level flood management plans lead towards effective and sustainable integrated flood management. So far no comprehensive flood management plan at basin level has been developed in Pakistan. In addition, flood management planning is hardly mainstreamed into national development policy.

\subsubsection{Investment Issues}

Pakistan suffered cumulative flood damage of US\$38.165 billion from 1947-2015 and invested PKR 29.35 billion (US\$279.524 million at the 2015 rate; 1 US\$ = PKR 105) to mitigate the floods effects during this period. This investment was made on implementation of 5410 flood projects. However, a larger part of investment was spent on relief and recovery by transferring financial resources to the flood victims from public funds [39]. This reflects a reactive approach to flood management.

\subsubsection{Flood Infrastructure Issues}

The present flood infrastructure in Pakistan is outdated of stemming from the 1850's. The oldest structures are in poor condition due to lack of adequate maintenance [40]. In Pakistan, main issues related to flood infrastructure include improper planning, design and implementation of flood protection infrastructure, partial implementation of flood works due to delay in approval, funding and construction and poor maintenance due to inadequate funds. There is no change in the design of embankment for the last decades. The SOPs (Standard Operating Procedures) used during flooding at dam sites, barrages, bridges and other infrastructure are not aligned optimally towards minimizing disastrous results of floods.

Water storage reservoirs considerably reduce shortduration floods, but their performance decreases during major floods. The Tarbela dam reduced the peak of 2010 flood by 35\% [41]. In Pakistan, reservoirs are primarily used for irrigation water storage and hydropower generation, with flood control only being a third consideration. Tarbela, Mangla and Chasma reservoirs of Pakistan are progressively losing their storage capacity due to sedimentation. Current storage capacity of these reservoirs by international standards is very low, making flood control a challenge. Climate change has been projected to aggravate floods. The situation of storage

Mehran University Research Journal of Engineering \& Technology, Volume 37, No. 2, April, 2018 [p-ISSN: 0254-7821, e-ISSN: 2413-7219] 
capacity loss and increased flood flows demands an urgent development of new and improvement of existing storage infrastructure [42].

\subsubsection{Lack of Effective Flood Preparedness}

In Pakistan, currently, lack of flood preparedness policies, strategies and actions aggravate the flood situation. The government's response to flooding is inadequate and does not address flood problems comprehensively and effectively.

\subsubsection{Lack of Effective Flood Fighting and Post- Flood Operations}

Currently, Pakistan lacks in effective flood fighting activities. The current flood fighting plans having no upgradation or innovation lack in integrated and holistic flood management strategy.

Pakistan also lacks in effective post-flood management activities including relief and sustained recovery due to poor institutional coordination and weaker accountability checks. The post-flood rehabilitation task is a major challenge. The rebuilding of the entire infrastructure including the irrigation channels, communication systems, roads, bridges, schools, and hospitals, in addition to accommodation of displaced people along with provision of food, water and sanitation facilities is a big and difficult task across the country. This entire process needs comprehensive policy and planning measures which are currently missing in Pakistan.

Currently, Pakistan also lacks in effective emergency relief plans. The provincial emergency authorities (PDMAs) have not well developed emergency relief plans and they have also not assigned clear emergency relief tasks to local emergencies authorities ((DDMAs).

\subsubsection{Lack of Community Awareness, Education and Training on Flood Hazards and Mitigation}

Generally local communities lack in comprehensive flood risk awareness and education in flood management. Weak coordination between flood managers and communities and lack of community's capacity to cope with floods are big issues to reduce flood effects [43]. Communications and outreach play an important role in reducing flood impacts through better information and awareness.

\subsubsection{Climate Change Impacts}

Various studies have predicted that climate change would aggravate floods in Pakistan due to high glacial melting and deicing of mountain caps and high monsoon rainfall [44]. The frequency of floods in Pakistan has substantially increased due to climate change in the recent years. So the intensifying impacts of climate change on flooding demands for a holistic, proactive and integrated approach for effective flood management. Pakistan lacks a serious commitment from high level to combat the challenge of climate change. Institutional framework is weak and the Ministry of Climate Change had been shrunk into a division with inadequate financial and human resources and inadequate capacity.

\subsubsection{Lack of Integrated Flood Management}

In Pakistan, traditional flood management focuses on only flood protection embankments and spurs having poor design and maintenance, barrages, regulation of reservoirs and flood fighting plans. The current flood fighting plans lack in integrated and holistic flood management strategy. Effective flood management cannot be achieved by only flood protection infrastructure and flood fighting plans. An integrated flood management approach is vital for effective flood management. 


\subsubsection{Flood Management Prospects}

The international experiences especially in USA, India and Bangladesh on effective flood management reveal that a combination of persistence, good institutions with enhanced capacity and effective coordination, effective flood policy and laws, participation of all concerned stakeholders, judicious investments in infrastructure, better maintenance of natural drainage paths, improved management of irrigation and drainage infrastructure, flood forecasting and early warning, watershed management, land use planning, floodplain zoning, flood fighting and post-flood operations can minimize flood damages. Adoption of the comprehensive measures depicted below would offer opportunities for effective and sustainable flood management resulting in minimum flood damages in Pakistan.

\subsubsection{Comprehensive Flood Policy}

Flood risks identification, flood strategies formulation and formulation of policies and programs to execute flood strategies are required for proactive flood management. The flood policy should be developed based on flood research which will lead towards development of an effective and sustainable flood management system. The flood policy should not consider only flood control rather it should consider flood risk management approach. A comprehensive flood policy must consider land use zoning, floodplain management, watershed management, environmental protection, forestation and water storages development. Flood policy should not only consider traditional structural and non-structural measures. Policies specific to flash flood management should also be developed.

\subsubsection{Comprehensive Flood Laws and Effective Enforcement}

Essential legislation, better governance and effective institutions are vital for effective flood management. The flood management legal structure should contain water laws, river laws, disaster management laws, land use planning and floodplain protection laws. Forest laws also need to be improved and effectively enforced.

\subsubsection{Improved Flood Planning}

Effective flood management requires comprehensive flood planning which should focus on basin level structural and non-structural actions that would result in sustainable use of natural resources, environmental protection, reduced vulnerability of floodplain populations to flood risks and reduced flood hazard risks.

\subsubsection{Integrating Flood Management into Development Policy, Planning, Program and Projects}

For sustainable development flood policy should be mainstreamed within the national development policy. Basin-wide flood management plan should be formulated considering the national development policy and plans. National flood plans and strategies need to be integrated in the plans and program of every sector and area of development.

\subsubsection{Enhanced Institutional Capacity and Coordination}

The capacity of flood institutions needs to be enhanced for effective flood management. The capability of PMD, WAPDA, Irrigation Departments and NDMA needs to be enhanced by hiring competent staff and using latest technologies. Improved interagency coordination is essential for effective flood management [45]. The coordination between PMD, Irrigation Departments, WAPDA, District Administration, Army, Police, Press and Public Representatives needs to be enhanced for effective flood management. 


\subsubsection{Improved Operation and Maintenance of Flood Infrastructure}

In Pakistan, most of embankments are in poor condition due to lack of proper maintenance and cannot serve the purpose of flood protection effectively. In order to improve their performance, there is a dire need to repair existing damaged embankments and construct new embankments [46].

Embankment design has by and large remained unchanged for the last decades. A large number of techniques are available that optimize embankment design in terms of cost and safety levels including use of geotextile and other new building material.

Effective monitoring and evaluation of flood infrastructure's conditions help identify rehabilitation and improvement needs of the flood infrastructure thereby help enhance its performance during flooding [47]. The flood embankments should be well maintained during dry period and should be inspected and repaired before the onset of flooding. Based on monitoring effective SOPs for flood structures need to be updated and improved considering their weak areas [48]. A closer look at the SOPs used during flooding at dam sites, barrages and other infrastructure like bridges etc. is vital to make sure they are aligned and practical. A contingency plan should also be developed to indicate the infrastructures coming in the flood route especially low lying areas, villages and towns. Survey of rivers should be conducted by utilizing modern technologies like imageries, digitization, bathymetries and total stations which result in speedy and accurate surveys. Model studies need to be conducted on river training works to help proper planning of flood protection schemes. The design and construction of flood structures should also be improved considering the experiences of recent floods. The capacity of rivers in Pakistan to accommodate floods has been compromised by the transformation of flood plains to areas with permanent habitation and because of the siltation of the main rivers. There is a need to increase the storage capacity of rivers by sediment management, regulating flood plain land use and applying other flood mitigations measures.

Due to limited role of existing major water reservoirs (Tarbela, Mangla \& Chashma) in flood manangement as a result of reduced storage capcity and small operation for floods, there is a dire need of development of new large reservoirs with major role in flood management [49]. There is a dire need to enhance water storage capacity by 22 BCM (Billion Cubic Meter) by 2025 to meet the future water and flood management requirements. Reservoir management needs to be improved to achieve irrigation, hydropower generation and flood control objectives [50]. Reservoir operation manuals should be developed to optimize flood moderation as well as other benefits.

Wetlands can contribute significantly towards flood management. Pakistan has more than 225 wetlands covering an area of 780,000 ha. These wetlands should be preserved to store floodwater. [51].

\subsubsection{Improved Drainage Infrastructure}

Currently, inadequate poorly maintained drainage infrastructure especially the distorted natural drainage network also aggravates the flooding problem in Pakistan. Railway lines, bunds, embankments, housing and industrial installations cause obstructions of flow and blockage of the natural drainage channels. Revival of natural waterways and improved operation and maintenance of existing drainage infrastructure is also vital for effective flood management. Development in flood plain areas or alteration of natural drainage systems significantly increases the risk of flood damage. The current rainfall patterns require development of a comprehensive multi-purpose drainage system by activation of old drainage routes [52]. There is a need for upgradation of drainage infrastructure. 


\subsubsection{Improved Flood Forecasting and Early Warning Capability}

Effective flood forecasting and early warning system plays in flood management. Currently, flood forecasting and early warning system of Pakistan has limited predictive capacity. To enhance system's predictive capacity its coverage needs to be extended to the entire Indus Basin. Flash floods forecasting should also be improved. Though considerable strengthening of flood forecasting has been done by adding weather radar and telemetric system still lot of effort is required to improve flood forecasting and warning system. Flood extent modelling is not yet standard practice and the changes of the hydrologic regime due to changing weather patterns is not taken into account. In some areas the forecasting of floods is difficult because of insufficient monitoring equipment and the fact that large parts of the catchment are located outside the country borders. The suite of flood routing and flood extent modelling does not seem to be forged into an integrated system. There are also ungauged (sub) basins which make forecasting more difficult.

\subsubsection{Effective Flood Preparedness}

DMAs are responsible to prepare a plan in advance for appropriate arrangements to minimize the flood impacts. Most commonly identified flood preparedness activities include: to raise the community awareness on floods attentiveness, preparation, planning, scheduling, response and improvement measures, the basic need materials must be in stock for emergency relief work, for advance and effective flood warning system we should install newer systems to forecast and communicate with people, and the management authorities are responsible to arrange the safe areas for temporary shelter in case of flood emergency and also to communicate with the community about those areas, to evacuate from the threatened places.
Currently, Pakistan lacks effective pre-flood planning. There are several institutional gaps and regulatory weaknesses in flood preparedness and response [53]. There is a dire need to develop a comprehensive flood plan prior to start of monsoon. Regular monitoring and evaluation of flood structures, strict use of standard operating procedures, and improved coordination among flood institutions would also lead towards effective flood preparedness to reduce flood damages [54].

The flood risk knowledge and awareness development also contributes significantly towards better preparedness and effective actions for flood management at any level. Adequate investments need to be made in flood preparedness and relief and early recovery effective management. Flood preparedness and response should be a national priority. A baseline risk identification study should be conducted to record flood risks through risk mapping across Pakistan. This study would play an important role in making effective flood preparedness [55].

\subsubsection{Integrating Climate Change into Flood Management}

The integration of climate change into flood management has been internationally recognized as a robust approach that can address flood risks and hazards effectively and sustainably [56]. Flood management without considering climate change may not prove effective rather it may aggravate flood risk [57]. The major drivers of hydrology change would include increased variability of monsoonal rainfalls and glacial melting in the Himalayan region of Pakistan threatening Indus river system flows. Glacier changes and monsoonal rainfalls variability must be considered for developing future flood management strategy. In Pakistan, currently, available climate information is often not being optimally utilized. Flood management should take into account the change in

Mehran University Research Journal of Engineering \& Technology, Volume 37, No. 2, April, 2018 [p-ISSN: 0254-7821, e-ISSN: 2413-7219] 
climate conditions. Pakistan’s lack of climate adaptability entails a loss of investment and even human lives. Such losses can be avoided by factoring in climate information into the flood management.

\subsubsection{Improved Watershed Management}

Improved watershed management, following the so-called 3R approach (recharge, retention and reuse) ensures that a larger proportion of the run-off is kept and buffered in the upper catchments. These can reduce the flood risks. Land-use changes may affect flood events positively and negatively. Deforestation aggravates flood problems. Pakistan has the highest deforestation rate in Asia. This has increased occurrence of floods in Pakistan. Deforestation should be discouraged and afforestation should be encouraged through a sustainable plan developed by the community, government, and other responsible agencies. It reflects an urgent need to improve watershed management.

Watershed management measures including afforestation, conservation of soil cover with vegetative development, detention ponds in the rivers catchment play an important role in decreasing flood peaks. The improved watershed management includes rehabilitation of the lost forest cover especially in Gilgit-Baltistan, FATA, AJK and KPK, development and implementation of a community-based forest restoration program and reassessment of the natural drainage paths, identification and reconfiguration of obstructions (caused by road, canals and railroad embankments) to allow flood waters to drain. It also includes development and operation of small dams, reservoirs, and water harvesting structures. This would enhance the retention capability of watershed in upstream areas that will reduce the flood risk in low lying downstream areas [58].

\subsubsection{Community-Based Flood Management Program}

Community-based efforts contribute significantly towards effective and sustainable flood control. Community participation is vital in relief, recovery, and reconstruction phases. Currently, Pakistan lacks in effective community participation in flood management. There should be significant involvement of local communities in identification of flood risks, development and execution of food plans. In order to enhance managing and resilience capacities of local communities, programs and projects should support heavily the local communities.

\subsubsection{Community Awareness, Education and Training on Flood Hazards and Management}

Flood risk education and awareness of community is vital to motivate people to take flood protection actions otherwise they underprepare and are largely unaware of the risk they face [59]. The greater effort should be made raising community awareness and preparedness for floods [60], [61]. The local capacity building enhances flood risk understanding and flood mitigation capacity [62]. Flood risk reduction training programs for community must provide clear knowledge about the floods preparation and evacuation procedures transform knowledge into practical actions and exercise trial and error mechanisms for further improvement. The implementation of a welldeveloped program on flood education, awareness, preparedness and warning for local communities offers a great potential for flood mitigation [63]. This will enhance resilience of the communities toward flood hazards thereby they would be able to cope with the floods in a better way. 


\subsubsection{Integrated Flood Management Strategy}

Integrated flood management considers a wide range of integrated multi-disciplinary flood management measures and involves more stakeholders and flood issues [64,65]. The integrated flood management approach includes development and enforcement of a comprehensive legal framework, effective floodplain zoning along with its enforcement, land use planning, improved forest laws and their effective enforcement and preservation of wetlands. Forestation, wetlands preservation and retention ponds can provide considerable flood control. Wetlands in Pakistan should be conserved and restored.

Land use planning is a major tool for reducing risks from floods and contributes towards sustainability and enhanced resilience. Risk-based planning provides an opportunity to move beyond planning for a natural hazard only (i.e. the likelihood of a flood event), to planning for the consequences of a flood event [66]. Currently, Pakistan lacks effective land-use planning controls.

In Pakistan, in the last four decades flood plains have been converted from areas with temporary use to places with permanent settlement in spite of land use regulations. Uncontrolled spatial planning causes obstacles in the flood plains. There is little attention to the effects that the present occupation of the flood plains has on the capacity of the river to discharge extreme floods. The flood plains need to be recognized and managed as areas where no permanent settlement should be allowed. Flood plain zoning and land use planning considerably reduce flood risk and its damages.

\section{CONCLUSION}

The recent floods in Pakistan that caused tremendous life and property loss reveal that current flood management mechanism in Pakistan is inadequate and reactive in approach. The present flood mechanism focusses on only flood control. It does not concentrate on flood management in a comprehensive manner. The climate change has intensified the vulnerability and flood risks. The situation demands for development of a sound flood management system. Though currently, a number of flood management and preparedness measures exist in Pakistan, but these measures have not improved the prospects of Pakistan in terms of sound flood management system. Currently, Pakistan faces the challenges of lack of comprehensive flood policy, planning and laws, lack of institutional capacity and coordination, inadequate flood and drainage infrastructure with poor operation and maintenance, lack of improved flood forecasting and early warning system, poor flood preparedness and lack of integrated flood management strategy. Pakistan also lacks in a comprehensive understanding of the Indus Basin hydrology affected by the climate change impacts that include changes in intensities and frequencies of monsoonal rainfall and rapid glacial melting and retreat.

In the aftermath of recent floods, Pakistan can no longer afford to do business as usual. In order to ensure effective and sustainable flood management Pakistan needs to improve its flood policy, planning and legislation, enhance institutional capacity, develop new and improve existing flood and drainage infrastructure with improved operation and maintenance, improve watershed management, continue improving flood forecasting and early warning system, improve flood preparedness, enhance community participation, and develop and implement integrated flood management strategy. Pakistan also needs to conduct research to gain an insight into climate change impacts on hydrology of the Indus Basin. The research output will provide a strong basis for formulation of a comprehensive and proactive flood management mechanism by improving the current flood management system which is inadequate and reactive in approach. 


\section{RECOMMENDATIONS}

The present review recommends that for effective and sustainable flood management, the Government of Pakistan needs to:

(i) Improve and approve flood policy and laws along with their effective implementation.

(ii) Integrate flood management that includes flood prevention, preparedness, mitigation and vulnerability reduction into national development policy, plan and program.

(iii) Strengthen flood institutions, interagency coordination, mechanisms and capacities at national and local level.

(iv) Continue to improve technical capability to forecast and warn against all sources of flooding (real-time, easy to communicate).

(v) Develop and implement a national adaptation plan to deal with climate change impacts. For this purpose, GoP should provide adequate financial resources to the Ministry of Climate Change and also invest in capacity development of climate professionals.

(vi) Develop and implement extensive community awareness raising programs to inform the community about flood hazards and preparedness for floods.

\section{ACKNOWLEDGEMENT}

The International Water Management Institute is in receipt of financial support from the United States Agency for International Development, and the United States Department of Agriculture, Foreign Agriculture Service through Grant \# 58-3148-3-196 and the CGIAR Research
Program on Water, Land and Ecosystems, which were used in part to support the present study. The study design, data collection, analysis and interpretation of the results are exclusively those of the author.

\section{REFERENCES}

[1] Arslan, M., Ullah, I., Baqar, M., and Shahid, N., "Evolution of Flood Management Policies of Pakistan and Causes of Flooding in Year 2010", Bulletin of Environmental Studies, Volume 1, No. 1, pp. 29-35, 2016.

[2] Price, G., and Mittra, S., "Water, Ecosystems and Energy in South Asia Making Cross-Border Collaboration Work”, Chatham House, the Royal Institute of International Affairs, 10 St James's Square, London SW1Y 4LE, [www.chathamhouse.org], June 2016.

[3] FFC (Federal Flood Commission), “Annual Flood Report 2015”, Office of the Chief Engineering Advisor \& Chairman, Federal Flood Commission, Government of Pakistan, Ministry of Water and Power, Islamabad, 2015.

[4] Sayed, S. A., and González, P. A., "Flood Disaster Profile of Pakistan: A Review”, Science Journal of Public Health, Volume 2, No. 3, pp. 144-149, [DOI: 10.11648/ j.sjph.20140203.11], 2014.

[5] Yaqub, M., Eren, B., and Doðan, E., "Flood Causes, Consequences and Protection Measures in Pakistan”, Disaster Science and Engineering, Volume 1, No. 1, pp. 8-16, 2015.

[6] Arshad, A., "Flood Warning App Developed as Part of NASA’s Space Challenge”, Pt: Pakistan Today, [http:// www.pakistantoday.com.pk], May 11, 2016.

[7] Ebrahim, Z., "Pakistan's New Plan to Embrace Floods", [https://www.thethirdpole.net/2015/07/29/pakistansnew-plan-to-embrace-floods], July 29, 2015.

[8] Khan, A., "Government Failure in Controlling Floods in Pakistan”, [http://potdrum.com/special-report/ government-failure-in-controlling-floods-in-pakistan], 2015. 
[9] NDMA (National Disaster Management Authority), “National Monsson Contingency Plan 2013”, 41p, Government of Pakistan, Islamabad, 2013.

[10] Kundzewicz, Z.W., Kanae, S., Seneviratne, S.I., Handmer, J., Nicholls, N., Peduzzi, P., Mechler, R., Bouwer, L.M., Arnell, N., Mach, K., Muir-Wood, R., Brakenridge, G.R., Kron, W., Benito, G., Honda, Y., Takahashi, K., and Sherstyukov, B., "Flood Risk and Climate Change: Global and Regional Perspectives”, Hydrological Sciences Journal, Volume 59, No. 1, pp. 1-28, [DOI: 10.1080/ 02626667.2013.857411], 2013.

[11] Federal Flood Commission, “Annual Flood Report 2010”, Office of the Chief Engineering Advisor \& Chairman, Federal Flood Commission, Government of Pakistan, Ministry of Water and Power, Islamabad, 2010.

[12] World Bank and Asian Development Bank, "Pakistan Floods 2010 Damage and Needs Assessment Report 2010”, Pakistan Development Forum, Islamabad, 1415 November 2010.

[13] Neelam, M., Afzal, I., Nawaz, M., and Ahmad, S.S., "Flood Damages and its Management Strategies (2010) in Layyah District, Pakistan”, International Journal of Scientific \& Engineering Research, Volume 5, No. 11, pp. 375-379, 2014.

[14] Qaddafi, S.M., "Flood Mitigation Strategy, Plans and Measures for Pakistan”, The Pakistan Spector, [http:// www.pkhope.com/flood-mitigation-strategy-plans-andmeasures-for-pakistan], 2010.

[15] Shabbir, A.H., "The Impact of Flood on Economy of Pakistan”, AgriHunt-A hunt for agricultural knowledge, [http://agrihunt.com/uncategorized/the-impact-of-floodon-economy-of-pakistan], July 22, 2016.

[16] World Bank and Asian Development Bank, "Damages and Needs Assessment Report 2011”, World Bank and Asian Development Bank, Islamabad, Pakistan, 2011.

[17] Federal Flood Commission, “Annual Flood Report 2012”, Office of the Chief Engineering Advisor \& Chairman, Federal Flood Commission, Government of Pakistan, Ministry of Water and Power, Islamabad, 2012.
[18] Pakistan Space \& Upper Atmosphere Research Commission and Food and Agriculture Organization of the United Nations, "Rapid Crop Damage Assessment. Pakistan: Floods/Rains 2012”, Series No. 4. Pakistan Space \& Upper Atmosphere Research Commission SUPARCO, Islamabad, October 30, 2012.

[19] National Disaster Management Authority, "Monsoon Weather Situation Report 2014”, Government of Pakistan, Climate Change Division, [http:// www.ndma.gov.pk/new/Documents/sitrep-8-9-2014.pdf], 7 September, 2014.

[20] Aslam, Q., "Climate Change and Fear of Flooding in Pakistan”, News Watch, 2016. [http://newswatch.pk/ 2016/07/climate-change-and-fear-of-flooding-inpakistan], 2016.

[21] Davies, R., "Pakistan - Officials Warn of Glacial Lake Outburst Floods”, [http://floodlist.com/asia/pakistanwarn-glacial-lake-outburst-floods-july-2016], 16 July, 2016.

[22] Qureshi, A. S., "Managing Floods in Pakistan: From Structural to Non-Structural Measures”, Paper \# 302 in Volume 34-2012 of Symposium on Emerging Phenomenon of Untimely Rains/Floods-2011 in Pakistan, Organized by Pakistan Engineering Congress at Lahore, Pakistan, [WWW.pecongress.org.pk], 2012.

[23] Friends of Democratic Pakistan Water Sector Task Force, "A Productive and Water-Secure Pakistan: Infrastructure, Institution and Strategy”, The Report of the Water Sector Task Force of the Friends of Democratic Pakistan, ADB Secretariat, Serena, Islamabad, Pakistan, 2012.

[24] Tariq, M.A.U.R., and van de Giesen, N, "Floods and Flood Management in Pakistan” Physics and Chemistry of the Earth, Parts A/B/C, Volumes 47-48, pp. 11-20, [DOI:10.1016/j.pce.2011.08.014], 2012.

[25] Judicial Flood Inquiry Tribunal, "Developing an Integrated Flood Management Plan-The Way Ahead”, Chapter-9, Report of 2010, Judicial Flood Inquiry Tribunal, [WWW. Punjab.gov.pk/sites/ Punjab.pitb.gov.pk/files/ch9.pdf], 2010. 
[26] Ali, A., "Indus Basin Floods: Mechanisms, Impacts, and Management”, Asian Development Bank. Mandaluyong City, Manila, Philippines. Publication Stock No. RPT125133-3, [WWW.adb.org], 2013.

Memon, N.A., Anwar, A., and Aslam, M., "Minimizing Flood Damages to Agriculture”, In: 73rd Annual Session 2014-2015 of the Pakistan Engineering Congress, Organized by the Pakistan Engineering Congress, Held at PEC Building Liberty Market, Gulberg III, Lahore, 24-27 December 2015.

[28] Ahmed, B., Wei, S., Fu, Y.G., Shabbir, M., Nabi, G., and Khan, K.U., "Effects of Floods Policy in Pakistan and Management Issues: (Case of District Dera-Ghazi Khan)”, International Journal of Advanced Research, Volume 2, No. 10, pp. 967-974, 2014

[29] National Disaster Management Authority, "National Disaster Management Guidelines: Management of Floods”, 135p., Government of India, [Web: www.ndma.gov.in], 2008.

[30] Abbas, A., Amjath-Babu, T.S., Kächele, H., Usman, M., and Müller, K., “An Overview of Flood Mitigation Strategy and Research Support in South Asia: Implications for Sustainable Flood Risk Management”, International Journal of Sustainable Development \& World Ecology, Volume 23, No. 1, pp. 98-111 [DOI: 10.1080/ 13504509.2015.1111954], 2015b.

[31] Dawn Newspaper, "Indus Basin Lacks Proper Flood Policy, Warns ADB”, [http://www.dawn.com/news/ 1049368/indus-basin-lacks-proper-flood-policy-warnsadb],13 October, 2013.

[32] Shrestha, A.B., and Bajracharya, S.R. (Editors), "Case Studies on Flash Flood Risk Management in the Himalayas: In Support of Specific Flash Flood Policies", 66p, Kathmandu: ICIMOD, [www.icimod.org/ publications], 2013.

[33] Hameed, K., "Integration of Strategic Environmental Assessment in Flood Management Planning, Lessons Learned from the International Experience-Case Pakistan”, IAIA13 Conference Proceedings, Impact Assessment the Next Generation, 33rd Annual Meeting of the International Association for Impact Assessment, Calgary Stampede BMO Centre, Calgary, Alberta, Canada, [www.iaia.org], 13-16 May 2013.
[34] Zeshan, A., and Khan, D.M.B., "Implementation of Disaster Risk Reduction Policy in Pakistan-An Evidence from Sialkot”, ISSRA Papers 2015 (1st Half): ISSRA Papers-The journal of Governance and Public Policy, Volume VII, No.1, pp.85-98, Institute for Strategic Studies, Research \& Analysis, National Defence University, Islamabad, Pakistan, [www.ndu.edu.pk/issra/ issra_pub-issra-paper-1st-half-2015.php], 2015.

[35] Afridi, M.A., and Siddiqui, M.A, "Floods and Rehabilitation: A Study of Problems, Perspectives and Socio-Economic Impacts on Sindh Province, Pakistan”, Degree Project for the Master's Program in Water Systems Technology Department of Land and Water Resources Engineering, Royal Institute of Technology (KTH), SE-100 44 Stockholm, Sweden. TRITA-LWR Degree Project 13:05, 37p., 2013.

[36] Azad, A. and McElhinney, H., "Ready or not Pakistan's Resilience to Disasters One Year on from the Floods", 150 Oxfam Briefing Paper, 36p, Oxfam International, [www.oxfam.org], 2011.

[37] Ramay, S.A., "What Needs to be Done to Manage Floods Better?” The Express Tribune, [http://tribune.com.pk/ story/762723/what-needs-to-be-done-to-manage-floodsbetter], September 15, 2014.

[38] Saeed, F., Suleri, A.Q., and Salik, K.M., "Planning for Floods: Now or Never”, Policy Brief No. 44, Sustainable Development Policy Institute, Islamabad, [www.sdpi.org], 2014.

[39] Abbas, A., Amjath-Babu, T.S., Kächele, H., and Klaus Müller, K., "Non-Structural Flood Risk Mitigation under Developing Country Conditions: An Analysis on the Determinants of Willingness to Pay for Flood Insurance in Rural Pakistan”, Natural Hazards, Volume 75, No. 3 , pp. 2119-2135, [DOI:10.1007/s11069-014-1415-X], $2015 a$.

[40] Sonneville, J.D., Steenbergen, F.V., and Saaf, E.J., "Dutch Risk Reduction-Team Scoping Mission Report Pakistan, DRR14PK01, Water Management and Flood Control in Pakistan”, pp. 52, Dutch Risk Reduction Team: Reducing the risk of water related disasters. The Kingdom of the Netherlands, [http://www.drrteam-dsswater.nl/wpcontent/uploads/2015/06/DRR-Scoping-Mission-Report20-April-2015-final.pdf], 2015. 
[41] Emami, K., “Adaptive Flood Management”, In Proceedings of the International Workshop on International Workshop on Floods in Pakistan 2010: Lessons Learnt and Way Forward, Organized and Held at the Auditorium of Pakistan Engineering Congress, Lahore, March 12, 2011.

[42] Organization for Economic Co-operation and Development, “OECD Reviews of Risk Management Policies, Seine Basin, Ile-de-France: Resilience to Major Floods”, pp. 27, OECD [https://www.oecd.org/gov/risk/ Flood-risk-management-seine-river-executive summary.pdf], 2014.

[43] Khan, I., "Towards Sustainable Flood Management in Upper Sindh, Pakistan (A Case Study of District Sukkur)”, Master Thesis, Department of Ecotechnology and Sustainable Building Engineering, Mid Sweden University, 2013.

[44] World Bank, “World Bank Report: Pakistan’s Water Economy: Running Dry”, 2005.

[45] Adnan, M., “Pakistan’s Crisis Management: Examining Proactive and Reactive Strategies”, Journal of Political Studies, Vol. 21, No. 1, pp. 161:177, 2014.

[46] Haq, I.U., "Management of High Floods”, In Proceedings of the International Workshop on International Workshop on Floods in Pakistan 2010: Lessons Learnt and Way Forward, Organized and Held at the Auditorium of Pakistan Engineering Congress, Lahore, March 12, 2011.

[47] Qadir, C.G., "Flood 2010 in Pakistan and its Damages", In Proceedings of the International Workshop on International Workshop on Floods in Pakistan 2010: Lessons Learnt and Way Forward, Organized and Held at the Auditorium of Pakistan Engineering Congress, Lahore, March 12, 2011.

[48] Haq, A.U., and Zaidi, S. M. A., "Flood 2010: The Event, Issues and Way Forward”, Paper Number 272, pp. 5174, in the Proceedings of the International Workshop on Floods in Pakistan-2010, Organized by Pakistan Engineering Congress and Held at the Auditorium of Pakistan Engineering Congress, Lahore, 12 March 2011.
[49] Ashfaq, M., "Floods in Pakistan 2010 (Lesson Learned \& Way Forward) in Agriculture Sector (A Success Story)”, In Proceedings of the International Workshop on International Workshop on Floods in Pakistan 2010: Lessons Learnt and Way Forward, Organized and held at the Auditorium of Pakistan Engineering Congress, Lahore, March 12, 2011.

[50] Laghari, A.N., Vanham, D., and Rauch, W., "The Indus Basin in the Framework of Current and Future Water Resources Management”, Hydrol. Earth Syst. Sci., 16, pp. 1063-1083, [www.hydrol-earth-syst-sci.net/16/ 1063/2012], [DOI: 10.5194/HESS-16-1063-2012], 2012.

[51] Hamid, Y., Anwar, A., Aslam, M., "Capture of Flood Waters”, In: 73rd Annual Session 2014-2015 of the Pakistan Engineering Congress, organized by the Pakistan Engineering Congress, held at PEC Building Liberty Market, Gulberg-III, Lahore, 24-27 December 2015.

[52] Iqbal, I., Iqbal, Z., and Ravan, S., "Effective Use of Space-Based Information to Monitor Disasters and its Impacts: Lessons Learnt from Floods in Pakistan”, SUPARCO, Pakistan, [www.suparco.gov.pk], 2014.

[53] Deen, S., "Pakistan 2010 floods: Policy Gaps in Disaster Preparedness and Response”, International Journal of Disaster Risk Reduction, Volume 12, pp. 341-349, 2015.

[54] AAP (Action Aid Pakistan) and I-SAPS (Institute of Social and Policy Sciences), "Floods 2010: Governance Issues in Disaster Risk Management”, Policy Dialogue Report, pp. 17, [http://i-saps.org/upload/ reportpublications/docs/1401030390.pdf], 2011.

[55] Malik, A.A., "The Pakistan Floods 2010: Public Policy Lessons”, Policy Brief Series Volume 1, No. 1, pp. 7, International Policy and Leadership Institute, 2011.

[56] Handmer, J., Mustelin, J. Belzer, D., Dalesa, M. Edwards, J., Farmer, N., Foster, H. Greimel, B., Harper, M., Kauhiona, H., Pearce, S., Yates, L., Vines, K. and Welegtabit, S., "Integrated Adaptation and Disaster Risk Reduction in Practice”, A Roundtable Report, RMIT University, Griffith University and the National Climate Change Adaptation Research Facility, Brisbane, Australia, 2014. 
[57] Asian Development Bank, “Operational Plan for Integrated Disaster Risk Management 2014-2020”, Mandaluyong City, Philippines: Asian Development Bank, [www.adb.org], 2014.

Mahmood, S., Khan, A.U.H., and Ullah, S., "Assessment of 2010 Flash Flood Causes and Associated Damages in Dir Valley, Khyber Pakhtunkhwa Pakistan”, International Journal of Disaster Risk Reduction, Volume 16, pp. 215-223, [http://dx.doi.org/10.1016/ j.ijdrr.2016.02.009 2212-4209/\& 2016], 2016.

Clarke, D. J., and Grenham, D., "Microinsurance and Natural Disasters: Challenges and Options", Environmental Science and Policy, Volume 27, pp. S89S98, [Doi: 10.1016/j.envsci.2012.06.005], 2013.

[60] Qasim, S., Qasim, M., Shrestha, R.P., Khan, A.N., Tun, K., and Ashraf, M., "Community Resilience to Flood Hazards in Khyber Pakhtunkhwa Province of Pakistan”, International Journal of Disaster Risk Reduction, Volume 18, pp. 100-106, [http://dx.doi.org/10.1016/ j.ijdrr.2016.03.009 2212-4209/\& 2016], September 2016.

[61] Rouse, H., "Flood Risk Management Research in New Zealand: Where are We, and Where are We Going?” GNS Science Report 2012/04. 77p, [Www.gns.cri.nz], 2012 .
[62]

Gall, M., Cutter, S.L., and Nguyen, K., "Incentives for Disaster Risk Management”, IRDR AIRDR Publication No. 2, Integrated Research on Disaster Risk (IRDR) C/O /Chinese Academy of Science Room B713, No. 9 Dengzhuang Nanlu Haidian District, Beijing, China, [www.irdrinternational.org], 2014.

[63] Melbourne Water Corporation, "Flood Management and Drainage Strategy”, Melbourne Water, 100 Wellington Parade, East Melbourne, PO Box 4342 Melbourne Victoria, [WWW: melbournewater.com.au], 2007.

[64] Sayers, P., Galloway, Y. L.i, G., Penning-Rowsell, E., Shen, F., Wen, K., Chen, Y., and Quesne, T.L., "Flood Risk Management: A Strategic Approach”, Paris, UNESCO, 2013.

[65] WMO (World Meteorological Organization), "Urban Flood Management in a Changing Climate”, Integrated Flood Management Tool Series, WMO/GWP Associated Program On Flood Management, World Meteorological Organization Communications and Public Affairs Office, Geneva, Switzerland, [Www.wmo.int], 2012.

[66] Saunders, W.S.A., and Kilvington, M., "Innovative Land Use Planning for Natural Hazard Risk Reduction: A Consequence-Driven Approach from New Zealand”, International Journal of Disaster Risk Reduction, Volume 18, pp. 244-255. [http://dx.doi.org/10.1016/ j.ijdrr.2016.07.002], 2016. 